\title{
Dacca: an Experiment in University Education in India.
}

7 HE transition phase, now in rapid progress in all matters connected with government in India, has also exercised a profound effect on university education. In many directions experiments have been made during the last few years. Eight new universities have come into being, a number of others are being dis-

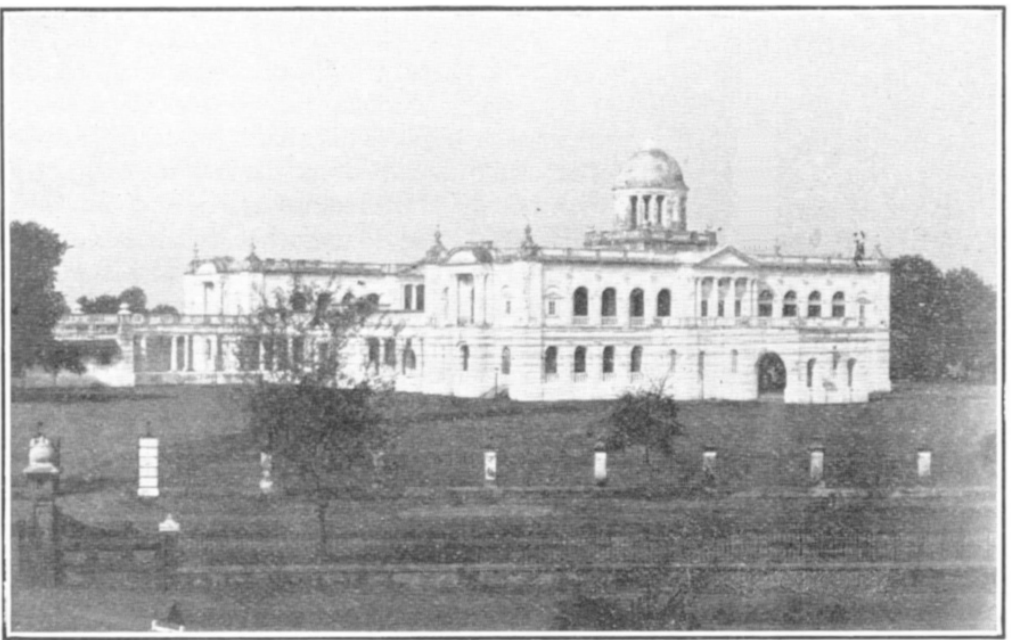

FIG. I.-University of Dacca. University Court House.

Registrar of the University of London, was appointed the first vice-chancellor.

While these decisions were being arrived at, the prospects of a really notable advance in Indian education were most hopeful. A number of suitable buildings, covering nearly a square mile in area, were immediately available. These had been erected, provided, with roads and suitably laid out, for the Government of Eastern Bengal and Assam, which came to an end in rgr 2 on the re-partition of the Provinces of Bengal, Bihar, and Assam. Included in these buildings were the premises of the Dacca College. The area assigned to the University is situated to the north-west of the city of Dacca and alongside the public park of Ramna, and is admirably suited to the needs of a modern residential university. Besides the site and the buildings, a large sum of money, amounting to some 60 lakhs of rupees (about 400,000l.), had been set aside by the Government of India for the needs of the new undertaking.

Steps were also taken to recruit the cussed, while in the older institutions, notably Calcutta and Lahore, an effort is being made to raise the standard of teaching, particularly in science. When it is remembered that many of these developments have taken place during a period of acute financial stringency, the strength of the national movement which has given birth to these changes will be evident.

In many respects the new University of Dacca, which was opened on July $\mathrm{r}$, $\mathrm{r} 92 \mathrm{r}$, is of special significance to those interested in the development of higher education in India. This university owes its foundation to the Calcutta University Commission, presided over by Sir Michael Sadler, and is an attempt to remedy, by means of an actual example, the abuses which had gradually grown up in India round the purely examining bodies of the older type. To many of the present university students in India, collegiate life, such as exists in Europe and the United States, is unknown; there are little or no facilities for sports and other forms of recrea-

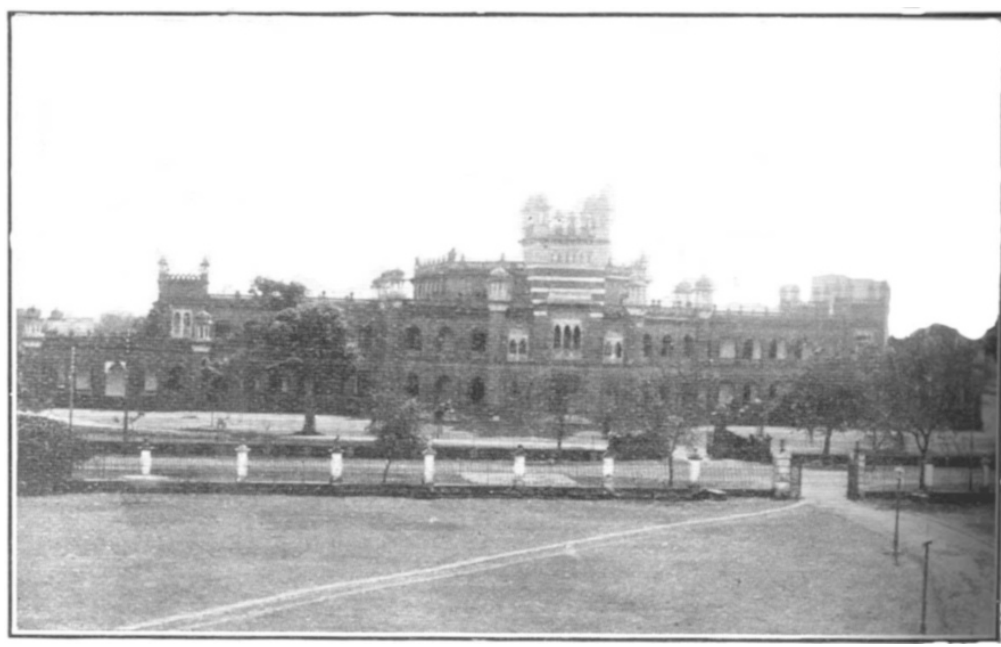

FIG. 2,-University of Dacca. Curzon Hall and Physics Laboratory. tion, while the inevitable examinations exercise far too great an influence on the teaching. It was felt by the members of the Sadler Commission that a new university, organised on the model of modern British universities, was essential if any real progress was to be made in higher education in India. Dacca was accordingly selected for the experiment, and one of the members of the Commission, Dr. P. J. Hartog, formerly Academic very best staff possible, and to make the teaching of science one of the main features of the University. Unfortunately, by the time Dr. Hartog arrived in India in 1920 , the financial situation had reached such a position that the Government of Bengal was compelled to stop all new developments. An era of severe retrenchment ensued, and the new University found itself sadly crippled. The sixty lakhs found its way into the treasury of the Bengal Government when the Reforms Scheme came into operation. Bengal, however, has admitted the moral claim of the University of Dacca to this sum, and has been releasing it at the rate of four lakhs of rupees a NO. 2900, VOL. I I 5$]$ 
year for capital in addition to a recurring grant of five lakhs. The total annual income and expenditure of the University are now about seven and a half lakhs of rupees (about 50,000l.).

In spite of the shortage of funds, however, the University came into being in I92 I with nearly a thousand students and every year the numbers have steadily increased. At the present time nearly 1400 students are in residence divided among the three faculties of Arts, Science and Law. The students, other than those who stay with relatives in the town, live in three residential colleges-known as the Dacca Hall, Muslim Hall and Jagannath Hall-round which the social and athletic life of the University mainly centres. Recently, a new and interesting development has taken place as a result of the residential system. Social service organisations, designed for the uplift of the degraded and the enlightenment of the ignorant, have taken firm root in the University and are doing good work.

On the teaching side, Dacca has broken new ground in several directions. A tutorial system has been established, and the students are taught how to use a library. The tutorial class, as designed at Dacca, is intended to counteract the inevitable evils of the examination room. Examination tends to discourage originality. The tutorial system is designed to foster individual effort, to ensure that each student shall be enabled to learn something of intellectual production as well as of reproduction, so that when he enters the world he will not find himself for the first time confronted with problems to which he had not been taught the answers beforehand. Besides the institution of the tutorial system, the University possesses a good library, the use of which forms an important part of the training of the students. The Sadler Commission in its report stated that in the colleges of some Indian universities, students of university courses read little more than their text-books. This cannot be said of Dacca. The last report shows that 33,982 books were borrowed from the University library during the year. These reforms in the teaching have had their inevitable result. Many of the advanced students have taken up research, and every year a growing number of original papers in languages, history, philosophy, economics, chemistry and physics are being published.

At the Convocation of the University of Dacca on March 6 last, His Excellency Lord Lytton, the Governor of Bengal, in conferring the degree of Doctor of Laws on the vice-chancellor, referred to Dr. Hartog's great services in having successfully established a modern university at Dacca, which though only four years old had already made a name for itself in the world. Lord Lytton stated that the establishment of the tutorial system was largely due to Dr. Hartog, who had worked with patience, with courage, and with industry, and their reward was the appreciation of all his colleagues. They greatly regretted that that would be the last Convocation at which they would see him as their vicechancellor.

\section{Obituary.}

Prof. Albin Haller, For. Mem. R.S.

A LBIN HALLER was born on March $7, \mathrm{x} 849$, the A eldest of a family of eleven children, at Felleringen, a small village in the Vosges, near Mulhouse. His father was a master carpenter and cabinet-maker, and his mother carried on a small hardware business. In due course he entered his father's workshop as an apprentice, but two years later, and as the result of a conference between his father and a pharmacist of the neighbourhood, young Haller left his native village and became a student in a pharmacy at Münster; his new master, Achille Gault, undertook the literary as well as the scientific education of his pupil, and later installed him with his brother, Léon Gault, a pharmacist at Colmar.

Thanks to the wise counsels and benevolent interest of these two pharmacists, Haller was able to pass his bachelor of science examinations at Strassburg in May I870. He volunteered at the outbreak of the war of $187 \circ$, was assigned to the army medical service, and was drafted to a hospital at Lyons. The close of hostilities found Haller in a difficult position; his father died, and his mother, left with a large family, decided to open a small hotel in order to set her eldest son free to continue his training; whilst the mother thus became a German subject, the son remained a Frenchman, and rejoined his first teacher, Achille Gault, in a pharmacy at Nancy. When the staff of the University of Strassburg was transferred to Nancy in $\mathbf{1 8 7 2}$, he became a student in the School of Pharmacy, and was awarded his diploma as a pharmacist in I873.

The training of a pharmacist in France often led, and still often leads, to a career in pure chemistry; this arises from the excellent chemical education given to the French pharmacist. Further, the fact that Alsace was the seat of many flourishing chemical industries had already attracted to chemistry many young Alsacians such as Wurtz, Friedel, Schutzenberger and Ch. Lauth. Haller's tastes and his many talents impelled him to forsake pharmacy and to devote himself to chemical science; he soon became well known as a chemical investigator, and took his degree of doctor of science at Paris in $\mathbf{1 8 7 9 .}$ He was appointed professor of chemistry at Nancy in 1885 , and professor of organic chemistry in $\mathbf{I} 898$; in 1899 he succeeded Friedel in the chair of organic chemistry at the Sorbonne, a position which he retained until his retirement last year under the age limit.

During the 'seventies of last century our chemical knowledge of camphor was but slight, partly because of the comparatively small number of camphor derivatives known; Haller attached himself particularly to the problems relating to this ketone and prepared large numbers of new derivatives. His first work related to the behaviour of sodiocamphor, and he was the first to prepare iodocamphor and cyanocamphor; the latter compound led to many new derivatives, such as homocamphoric acid, the study of which threw light on the constitution of camphor itself. He made an exhaustive

NO. 2900, VOL. I I 5$]$ 